excellent (see photographs). Canals, (?) gonads and mouth structures are frequently clearly visible, and in one form, Beltanella, a velar membrane is present.

Now that a considerable amount of new material is available for description and comparison, it is hoped that a more complete study of these interesting forms will be possible. Criticisms and suggestions would be most helpful in the continuation of this study.

Department of Mines, Flinders Street, Adelaide.

Dec. 15.

${ }^{1}$ Trans. Roy. Soc. South Austral., 71 (2) (1947).

REG. C. SPRIGG

\section{Cementiferous Paints and their Uses}

The reference by Dr. L. A. Jordan ${ }^{1}$ to the possibilities of cementiferous paints as fireproof coverings for the interior of warships makes it advisable to supply an earlier chapter in the history of these paints. The fact that metallic particles interact with certain chlorides to give cement-like masses was noticed by Dr. U. R. Evans, of the University of Cambridge, when working on a Service problem in 1940. He later extended the idea to produce water paints which could be applied to a wet steel surface, and which provided cathodic protection to the steel, even where exposed at discontinuities. Such a paint was put into industrial use in 1942 in a plant where rapid corrosion cracking had caused frequent stop. pages in a process of high war priority, and has been in use ever since. Here, the conditions are quite exceptional, and it is unlikely that the paints have any advantage in the average terrestrial situation.

Thornhill and Mayne carried out at Cambridge detailed study of the setting and protective mechanism, working for the Iron and Steel Institute Corrosion Committee (now the British Iron and Steel Research Association Corrosion Committee). Much work was also carried out, first by the Cambridge investigators, later at Caernarvon by J. C. Hudson, and finally at Millport by $K$. A. Pyefinch, on the possibilities of these paints for protecting steel plates immersed in sea-water; the results have been encouraging.

The Admiralty is represented on the Corrosion Committee, and the idea that the paints might be useful in combating the menace of rapidly spreading fires (such as occurs in ships painted internally with oil paints) appealed to those working on paint in the Admiralty Chemical Department at Portsmouth. Thornhill carried out some experiments late in 1943 on cementiferous fireproof paints, and took samples to Portsmouth in 1944. These were tested by the Admiralty chemists, who reported the coats to be insufficiently resistant to abrasion. Mayne then suggested the use of an overlying silica coat produced by means of ethyl silicate. Apparently this has solved the problem. Meanwhile, the Admiralty chemists appear to have continued researches on the paints, and have evidently achieved notable advances by the addition of industrial spirit, which allows the paints to be kept in a ready-mixed condition.

It is understood that ship trials have been carried out by the Admiralty, with encouraging results, of the possibilities of these paints as underwater protection paints.
Dr. U. R. Evans is anxious to emphasize the fact that these paints are unlikely to be of value except in certain special situations. Unauthorized statements seem to have appeared in the technical Press, and these have evidently led to misunderstanding. It can only lead to disappointment to apply a paint-or anything else-in the wrong situation.

\section{G. Wesley Austin}

(Chairman, Corrosion Committee,

British Iron and Steel Research Association Department of Metallurgy, Cambridge.

${ }^{1}$ Jordan, L. A., Nature. 160. 216 (1947).

\section{Flint Flaking}

WITH reference to the letter from Dr. T. T. Paterson under the title "Earliest Known Prehistoric Industry"', I wish to express my indebtedness to him for having brought his new discoveries for my exam. ination at home, so that I could compare them with my collection of natural flakings. I have been familiar with patches of intensive flaking below the Weybourne Crag for many years ${ }^{2}$. On some I have counted 50 per cent of flaking among the stones-a not unusual frequency.

The evidences of localized sites may be misleading. For example, the flaking on such a site may be all of one date; but before drawing a conclusion one must inquire whether on a wider area an identical type of flaking is of miscellaneous dates. Again, an associated group of flaking is not necessarily a human working, it may be a 'Nature's workshop'; in other cases, abraded flakings have been drifted together upon the sub-Crag floor.

Neither this, nor any other disputed group, carries flaking that is superior to that from the sub-Eocene site at Grays. This occurred in the Bullhead Bed, locally modified by the addition of large flints brought in through solution of the underlying Chalk. Some flaking is general in the Bullhead Bed; but this was a localized site of special character, which, in other circumstances, could well have been mistaken for a human industry ${ }^{3}$.

My point of view is that while it is not possible to distinguish human from natural flaking upon every separate specimen, I am convinced that mechanical movements under pressure, concussions and the like produce their respective groups of forms which are recognizable ${ }^{4}$. To the best of my judgment, the sub. Crag flakings conform to the distinctive characteristics of movements under pressure.

My tentative suggestion is that the whole of the effects of crushing, striation and flaking observed among the flints of the Crag sea-floor are due to the grounding of floating ice. At least, purely mechanical effects due to that, or some other cause, are conspicuous, and I submit that the problem of this remarkable flaking, with its rostro-carinates, flakes and edge-chipping, should be considered as a whole in association with the physical evidences.

Sherwood, S. HazzLEDINE Warren

Loughton, Essex.

${ }^{1}$ Nature, 161, 278 (1948).

"Warren, S. H., Geol. Mag., 309 (1924).

${ }^{3}$ Warren, S. H., Quart. J. Geol. Soc., 76, 238 (1920)

- Warren, S. IL., J. Roy. Anthrop. Inst., 44, 412 (1914); Proc. Bristol Spel. Soc., 302 (1925); Es8ex Nat., 27, 89 (1941). 